\title{
Alpine Landscapes of Health: The Swiss Whey Cure and Therapeutic Tourism between $175^{\circ}$ and 1870
}

\author{
Barbara Orland
}

The notion that landscapes influence human health can be traced back at least to the Hippocratic treatise On Airs, Waters, and Places. ${ }^{1}$ The author explained how the environment could cause certain illnesses, and he assumed that people inherit certain physical and mental features from their environment, e.g. differences in character or complexion. People who "inhabit a country which is mountainous, rugged, elevated, and well-watered, and where the changes of the seasons are very great" are likely to be tall, and have character qualities of endurance, ferociousness and courage. ${ }^{2}$ Apart from this, all living beings should keep a constant balancing of the so-called six Res Non-Naturales (air; food and drink; excretions; sleep; movement and rest; and emotions) in order to serve their health and well-being. Prevention was one of the cornerstones of ancient medicine. ${ }^{3}$

This Hippocratic association between environment and health, further elaborated through the medical and natural philosophical discourses of more than a millennium, ${ }^{4}$ was still accepted by numerous descriptions of the Alpine territory of the late 18th and early 19th century. An unnamed author of the German Morgenblatt für gebildete Leser wrote, "that at an elevation everything is finer and better than in the lowlands. He [Hippocrates, Bo] proves that as a rule the mountain-dwellers are of stronger and nobler character, and that also

1 Hippocrates, On Airs, Waters, and Places, trans. Francis Adams, accessed on 3July 2018. http:// classics.mit.edu//Hippocrates/airwatpl.html.

2 Ibid.

3 Sandra Cavallo and Tessa Storey, eds., Conserving Health in Early Modern Culture. Bodies and Environments in Italy and England (Manchester: Manchester University Press, 2017); Albrecht Classen, ed., Bodily and Spiritual Hygiene in Medieval and Early Modern Literature: Explorations of Textual Presentations of Filth and Water (Berlin, Boston: De Gruyter, 2017).

4 David Cantor, ed. Reinventing Hippocrates (Ashgate: Aldershot, 2002); Frederick II Sargent, Hippocratic Heritage: A History of Ideas about Weather and Human Health (New York: Pergamon Press, 1982). 
the air, water, plants, and all other objects in nature are purified and strengthened by the influence of elevation." ${ }^{5}$ So strong, in fact, was the link between environment (particularly meteorology) and medicine that the term "character" occasionally retained its ancient medical significance, and - in the case of the Alpine herdsmen - was transformed into a kind of racial trope. The British journalist Frederic Shoberl wrote:

The herdsmen of Appenzell, accustomed to live continually in mountain solitudes, have something wild in their appearance. A jacket and trousers constitute almost the whole of their dress, and milk is their chief subsistence. The purity of the air and water of their mountains, the aromatic qualities of the milk on which they live, the liberty which they enjoy, and the share which they have in the government of their country, all contribute to that liveliness, which distinguishes them from the rest of the Swiss, and which frequently inspires them with original repartees. ${ }^{6}$

In this paper, I will elaborate how such opinions developed at least since the middle of the 18th century. ${ }^{7}$ Not only physicians, but also innkeepers and herdsmen of the canton Appenzell were among the first to become acquainted with the neo-Hippocratic enthusiasm of the day, and assessed the mountainous

5 "Schon Hippokrates macht die Bemerkung, daß auf den Höhen alles feiner und besser sey als in den Ebenen. Er beweist, daß die Bergbewohner in der Regel kräftigere und edlere Naturen sind und daß auch auf die Luft, auf das Wasser, auf die Pflanzen und alle Gegenstände in der Natur die Höhen eben so einen läuternden und kräftigenden Einfluß üben. Auch in den Alpen hat man vielfach Gelegenheit, diese alte hippokratische Behauptung bestätigt zu finden." Morgenblatt für gebildete Leser, no. 3, January 3 (1849): 5 .

6 Frederic Shoberl, The World in Miniature. Switzerland, Containing a Description of the Characters, Manners, Customs, Diversions, Dress \&cc. of the People of that Country in General, and of the Inhabitants of the twenty-two Cantons in particular (London: R. Ackermann, 1827), 140.

7 Such arguments could already be found in the works of Johann Jakob Scheuchzer. See e.g. Simona Boscani Leoni, "Tra Zurigo e le Alpi:le 'Lettres des Grisons' di Johann Jakob Scheuchzer (1672-1733). Dinamiche della comunicazione erudita all'inizio del Settecento," in Die Alpen! Zur europäischen Wahrnehmungsgeschichte seit der Renaissance - Les Alpes! Pour une histoire de la perception européenne depuis la Renaissance, ed. J. Mathieu and S. Boscani Leoni (Bern, Berlin, Bruxelles: Peter Lang, 2005). See further e.g. Daniela Vaj, "Le Bon air des Alpes et le développement des stations climatiques d'altitude," in Bon air des Alpes: des stations climatiques au tourisme de bien-être: actes du colloque, Sierre, 7-8.10.2004-Die gute Alpenluft: von den Luftkurorten zum Wellnesstourismus: Tagungsband, Siders, 7.-8.10.2004, ed. HES-so Valais (Sierre: HES-so Valais, 2007); Daniela Vaj, "La géographie médicale et l'immunité phtisique des altitudes aux sources d'une hypothèse thérapeutique - [Medical Geography and Phthisic Immunity in the High Altitudes: The Origins of a Therapeutic Hypothesis]," Revue de géographie alpine - Journal of Alpine Research 93, no. 1 (2005). 
environment as a reservoir of health-promoting sources. They developed the so-called Gaisschottenkur (goat's whey cure) that made a name for itself for about a century between roughly 1750 and the end of the 19th century. They transformed a rural environment into fashionable health resorts that became much en vogue among the European bourgeoisie. In his benevolent report on Swiss milk diets, one British physician reflected in 1869: "There is a general feeling in favour of Swiss whey; and if they are not in Switzerland, patients are gratified to learn that the whey is made by a native of Appenzell, and still better pleased, if the said native shows himself in his national costume." ${ }^{8}$ Yet what was Swiss about the whey cure? How were representations of the landscape and the local habits meshed with neo-Hippocratic ideas about health and medicine? Referring to folk cultures and rural practices of milk consumption, travellers to the Swiss mountains most often emphasized the importance of local knowledge in their search for therapeutic landscapes. ${ }^{9}$ However, as will be shown in this paper, the whey cure that laid the foundation for the establishment of Swiss health resorts was in fact an invention of the late $18^{\text {th }}$ century. Previously whey had been considered an unattractive substance for nourishment and dairy business.

Until now historians have mentioned the Swiss whey cure as an anecdote in the history of Alpine tourism. ${ }^{10}$ When the Swiss mountains became a tourist destination in the late 18th and early 19th century, very soon the territory and its climate were detected as a "therapeutic landscape" with fresh air, healing herbs, and milk as an "extraordinary fluid."11 Historians have described how the interest in the sublime mountain landscapes attracted visitors on their Grand Tour, and as a romantic condemnation of urban living conditions in cities that

John Macpherson, The Baths and Wells of Europe: Their Action and Uses, with Hints on Change of Air and Diet Cures (London: Macmillan and Co, 1869), 320.

9 See e.g., Gabriel Rüsch, Heiden und seine Molkenkuranstalt im Freihof (Trogen: Schläpfer, 1854), 17 .

10 Susan R. Barton, Healthy Living in the Alps: The Origins of Winter Tourism in Switzerland, 1860-1914 (Manchester: Manchester University Press, 2008), 8-12; Hans Peter Treichler, "Molken, Milch und Traubenberge. Neue Ansätze im Kurwesen," in Zauberberge. Die Schweiz als Kraftraum und Sanatorium, ed. Felix Graf and Eberhard Wolff (Baden: hier + jetzt, 2010).

11 Heini Hofmann, Gesundheits-Mythos St. Moritz: Sauerwasser, Gebirgssonne, Höhenklima (St. Moritz: Montabella-Verlag, 2011), 32. Therapeutic landscape is a concept mainly used by geographers and anthropologists, see e.g. Ulrich Gebhard and Thomas Kistemann, eds., Landschaft, Identität und Gesundheit. Zum Konzept der therapeutischen Landschaften (Wiesbaden: Springer vs, 2016). 
were said to be breeding grounds for diseases. ${ }^{12}$ It is a commonly held view that some places in the Alps already in the $15^{\text {th }}$ and 16 th century had a reputation as places of healing waters, firstly as an aristocratic life style and then as medical places that should attract the ill and convalescents of all classes. ${ }^{13}$ The spa of the later 18th century played an important role in the erosion of the barriers between the classes, historian Karl Wood argued, it was influential in the development of a new Bürgertum. ${ }^{14}$

And yet, despite many details, most narratives on the Alpine bathing traditions and health resorts tend to treat the landscape as a kind of precondition of businesses that had an independent existence beyond the realm of human meanings. Primarily, class and social relations anchor the spa histories, and are combined with enquiries into the spa as a commercial enterprise. Few studies mention that early modern bathing manuals conventionally start their content with a description of the location, or ask how the healing waters were generated from the surrounding soil, received the "visceribus terrae" and the properties of minerals. ${ }^{15}$ Little interest has been directed to the authority of natural history descriptions of Alpine nature, the medical discourses and scientific investigations of Alpine plants, minerals, waters etc., and particularly the Alps as a "space of healing and recreation."16 By contrast, geographers and

12 Andrew Beattie, The Alps: A Cultural History (Oxford: Oxford University Press, 2006), $124-44$.

13 Werner Vogler, "Heilbäder in den Alpen im Spätmittelalter und in der Renaissance am Beispiel von Pfäfers," in Die Alpen als Heilungs - und Erholungsraum. Historikertagung in Meran - Le alpi: luogo di cura e riposo : convegno storico a Merano : 19.-21.X.1988, ed. Josef Nössing (Bozen: Verlagsanstalt Athesia, 1994); Richard Palmer, "In this our lightye and learned tyme': Italian Baths in the Era of the Renaissance," in The Medical History of Water and Spas, ed. Roy Porter (London: Wellcome Institute for the History of Medicine, 1990); Margrit Wyder, Kräuter, Kröpfe, Höhenkuren: die Alpen in der Medizin - die Medizin in den Alpen; Texte aus zehn Jahrhunderten (Zurich: Verlag NZZ, 2003), 43.

14 Karl E. Wood, Health and Hazard: Spa Culture and the Social History of Medicine in the Nineteenth Century (Newcastle upon Tyne: Cambridge Scholars Publishing, 2012), 19-21.

15 Frank Fürbeth, "Adaptionen gelehrten Wissens für laikale Zwecke in der Bäderheilkunde der frühen Neuzeit," in Wissenschaftsgeschichte und Geschichte des Wissens im Dialog Connecting Science and Knowledge: Schauplätze der Forschung, ed. Kaspar von Greyerz, Silvia Flubacher, and Philipp Senn (Göttingen: V\&R unipress, 2013), 228.

16 Christa Habrich, "Medizin- und naturwissenschaftshistorische Aspekte der Alpen als Heilungs- und Erholungsraum," in Die Alpen als Heilungs- und Erholungsraum. Historikertagung in Meran - Le alpi : luogo di cura e riposo : convegno storico a Merano : 19.-21.X.1988, ed. Josef Nössing (Bozen: Verlagsanstalt Athesia, 1994), 11; Simona BoscaniLeoni, ed. Wissenschaft - Berge - Ideologien. Johann Jakob Scheuchzer (1672-1733) und die frühneuzeitliche Naturforschung - Scienza - montagna - ideologie. Johann Jakob Scheuchzer (1672-1733) e la ricerca naturalistica in epoca moderna (Basel: Schwabe, 2010); Claude Reichler, La montagne réinventée: Géographes, naturalistes et sociétés (XVIII ${ }^{e}-X X^{e}$ 
anthropologists interested in the historical changes of Alpine landscapes, commonly view the mountainous landscapes as cultural constructions. To them, changes in the Alps are not merely a by-product of social, economic and political developments, but a complex system of regional experiences, practices, and symbols of identities. ${ }^{17}$ The focus is mainly on the relation between the natural environment, economy, work, and identity - the "nationalisation of nature" that transformed the Alps into "a national mass symbol," as Oliver Zimmer put it, ${ }^{18}$ with tourism as a rare issue in this respect. ${ }^{19}$ Histories of Alpine agriculture in turn taught us to distinguish between the land created by agricultural work and the popular imagery of an area that tends to freeze the existing landscape as natural scenery. ${ }^{20}$

There remains scope for further research to complete the picture of the Alps as a landscape of health and healthcare, not only in a strict geographic sense. ${ }^{21}$

siècles) = Reinventing Mountain Areas: Geographers, Naturalists and Society (18th-2oth centuries) (Grenoble: Revue de géographie alpine (Institut de Géographie Alpine), 1994); Reichler, La découverte des Alpes et la question du paysage (Chêne-Bourg: Georg, 2002); Silvia Flubacher, "Alpen-Tiere. Lokale Wissenswelten in der schweizerischen Naturgeschichtsschreibung," in Wissenschaftsgeschichte und Geschichte des Wissens im Dialog - Connecting Science and Knowledge: Schauplätze der Forschung, ed. Kaspar von Greyerz, Silvia Flubacher, and Philipp Senn (Göttingen: V\&R unipress, 2013). The chemical analysis of mineral waters has attracted some interest by historians of science. See e.g. Noel G. Coley, "Physicians, Chemists and the Analysis of Mineral Waters: 'The most difficult part of Chemistry', in The Medical History of Water and Spas, ed. Roy Porter (London: Wellcome Institute for the History of Medicine, 199o); Matthew Daniel Eddy, "The Sparkling Nectar of Spas, or, Mineral Water as a Medically Commodifiable Material in the Province, 1770-1805," in Materials and Expertise in Early Modern Europe. Between Market and Laboratory, ed. Ursula Klein and Emma C. Spary (Chicago, London: The University of Chicago Press, 2010).

17 Among a voluminous literature, see the different issues of the journal: Association Internationale pour l'Histoire des Alpes, ed. Histoire des Alpes (Zurich: Chronos, 19962018); Jon Mathieu, Norman Backhaus, Katja Hürlimann, and Matthias Bürgi, eds., Geschichte der Landschaft in der Schweiz. Von der Eiszeit bis zur Gegenwart (Zurich: Orell Füssli, 2016); Werner Bätzing, Die Alpen: Geschichte und Zukunft einer europäischen Kulturlandschaft, 4th. rev. ed. (Munich: Beck, 2015).

18 Oliver Zimmer, "In Search of Natural Identity: Alpine Landscape and the Reconstruction of the Swiss Nation," Comparative Studies in Society and History 40, no. 4 (1998).

19 Laurent Tissot, "From Alpine Tourism to the 'Alpinization' of Tourism," in Touring Beyond the Nation: A Transnational Approach to European Tourism History, ed. Eric G. E. Zuelow (Farnham: Ashgate, 2011).

$20 \quad$ Jon Mathieu, Eine Agrargeschichte der inneren Alpen. Graubünden, Tessin, Wallis 15001800 (Zurich: Chronos-Verlag, 1992); Barbara Orland, "Alpine Milk: Dairy Farming as a Pre-modern Strategy of Land Use," Environment and History 3 (2004).

21 Historical research on Alpine spas concentrates on Swiss and German spas, more or less on Italy, Austria and the Eastern Alps, if authors do not just explore just one place (e.g. 
Notable research on other regions highlights the extent to which scholarly debates about the cause and effect of directly observed natural phenomena influenced hygienic, dietetic and therapeutic practices. ${ }^{22}$ As Albrecht Classen put it, throughout the centuries there existed much discussion about the clean water or fresh and healthier air of some regions, making medical experts to early environmentalists, who offered very practical advice that could be easily combined with folklore prescriptions. ${ }^{23}$ Johann Jakob Scheuchzer's consideration of the bath of Pfäfers relied on an eclectic collection of knowledge from different sources, as Philipp Senn discovered, ${ }^{24}$ religion contributed to the relation between popular culture and healing practices, ${ }^{25}$ and knowledge could been imported from other regions. ${ }^{26}$

Taking inspiration from these works, this chapter will consider how diverse actors emphasized the constitutive force of landscape, agriculture and diet in order to allure urban visitors and patients to enjoy a drinking cure in a rural village in Switzerland. I will start my description with the case of the village of Gais in the Swiss canton Appenzell, which was said to be the first place in Switzerland where whey cures were invented in 1749. My intention is to offer a description of the methods and rhetoric used to define an Alpine health resort

Davos). Christian Schürer, Der Traum von Heilung. Eine Geschichte der Höhenkur zur Behandlung der Lungentuberkulose (Baden: hier + jetzt, 2017).

Raingard Esser and Thomas Fuchs, eds., Bäder und Kuren in der Aufklärung: Medizinaldiskurs und Freizeitvergnügen (Berlin: Berliner Wissenschafts-Verlag, 2003); Elizabeth Neswald, "Asserting Medical Identities in Mid-Nineteenth Century Ireland: the Case of the Water Cure in Cork," in Science and Technology in Nineteenth-Century Ireland, ed. Janina Adelman and Eadaoin Agnew (Dublin: Four Courts Press, 2010).

23 Albrecht Classen, "Introduction: Bathing, Health Care, Medicine, and Water in the Middle Ages and Early Modern Age," in Bodily and Spiritual Hygiene in Medieval and Early Modern Literature: Explorations of Textual Presentations of Filth and Water, ed. Albrecht Classen (Berlin, Boston: De Gruyter, 2017), 76.

24 Philipp Senn, "Forscher vor Ort. Johann Jakob Scheuchzer (1672-1733), Bündner Gönner und die Balneologie," in Wissenschaftsgeschichte und Geschichte des Wissens im DialogConnecting Science and Knowledge: Schauplätze der Forschung, ed. Kaspar von Greyerz, Silvia Flubacher, and Philipp Senn (Göttingen: V\&R unipress, 2013), 276.

25 Ute Lotz-Heumann, "Finding a Cure. Representations of Holy Wells and Healing Waters in Early Modern Germany," in Wissenschaftsgeschichte und Geschichte des Wissens im Dialog - Connecting Science and Knowledge: Schauplätze der Forschung, ed. Kaspar von Greyerz, Silvia Flubacher, and Philipp Senn (Göttingen: V\&R unipress, 2013), 233-54; Alexandra Walsham, The Reformation of the Landscape. Religion, Identity, and Memory in Early Modern Britain and Ireland (Oxford: Oxford University Press, 2011).

26 Vladimir Jankovic, "The Last Resort: A British Perspective on the Medical South, 18151870," Journal of Intercultural Studies 27, No. 3 (2006). See also the different case studies in: John K. Walton, ed. Mineral Springs Resorts in Global Perspective: Spa Histories (London, New York: Routledge 2014). 
and particularly whey as a local agricultural product of therapeutic significance. The connection between Alpine landscape and health as materialized in the whey cure did, however, slowly cease after the turn of the 19th century, although businesses still went quite well for some decades. The following section considers how science affected attitudes associated with the nature of the mountainous environment and altered assumptions about the medical value of animal milk. I will close this paper by bringing some of the arguments into the foreground that were responsible for the decline of the whey cure business during the second part of the 19th century.

By the early 1800 s, a story circulated throughout the European medical community of how the first whey cure had been invented in Switzerland. The physician Johann Heinrich Heim (1802-1876), a native of the village that stood at the heart of the narrative, disseminated the story like this: ${ }^{27}$ In the year 1749, a Dr Meyer of Arbon in canton Thurgau advised his brother-in-law, a Mr Steinbrüchel of Zurich, to try a therapy with milk. The patient, who suffered from a chest disease, was advised to undertake the cure in the little village Gais in the Swiss canton of Appenzell. The innkeeper Hans-Ulrich Heim (1720-1814) of the Gasthof zum Ochsen [and grandfather of Johann Heinrich Heim] instructed local herdsmen to deliver fresh and warm goat's whey every morning. After several weeks the man was cured and returned home. News of this cure rapidly spread around medical circles, so that other doctors started to send patients to Gais. During the next decades, Gais - "a village of cheerful appearance" 28 - became a renowned centre for the so-called Gaisschottenkur (goat's whey cure). Further establishments were built up during the next decades, firstly in the region, among them in Weissbad, Trogen, Appenzell and Heinrichsbad near Herisau. From there, the cure - most often connoted with Swiss Alpine nature - spread to other mountain regions, mainly

27 Joh. Heinrich Heim, Die Heilkräfte der Alpenziegen-Molken und der Molkenkurort Gais (Zurich: Schultheß, 1844), 96, 97. See also Fr.[iedrich] K. v. Kronfels, Gais, Weisbad und die Molkenkuren im Canton Appenzell (Constance: W. Wallis, 1826), 39-40. Herman Weber, a physician at the German Hospital in London, disseminated the story in Great Britain: Herman Weber, "Notes on the Climate of the Swiss Alps, and on some of their Health Resorts and Spas," The Dublin Quarterly Journal of Medical Science 37, no. 2 (1864): 333-34.

Weber, "Notes on the Climate," 362. 
in Switzerland, Austria, Bavaria, but Gais remained the place where the story of the overwhelming success of a specific health resort had its beginning. ${ }^{29}$

Before I can discuss this fashionable story of an invention, we have to rethink some of the preconditions of the spa culture. From a modern perspective, Gais needed three basic components to become a whey spa - the natural resources of sufficient pasture, animals and milk, in addition "spa" facilities that do not necessarily depend on natural resources, and a therapeutic system based on milk/whey. To begin with the last aspect, it is well known in medical history that at least since antiquity milk has been recognized as having a healthy effect on people. Physicians, healers and lay people used milk of all sorts in the regular treatment and dietary care for patients. ${ }^{30}$ Old schemes of materia medica found empirically in the earliest time of humankind were largely used into the 18th century, and particularly enlightened medicine with its emphasis on Hippocratic theory and practice had become a master in the formulation of past traditions. ${ }^{31}$ Occasionally, contemporary authors labelled milk cures as a controlled empirical therapy of the past or even quoted from Plinius, Hippocratic and Galenic texts to verify their prescriptions. ${ }^{32}$

29 There exists a wealth of printed sources on the whey spa culture of the 19th century, see, for instance, Gabriel Rüsch, Anleitung zu dem richtigen Gebrauche der Bade- und Trinkcuren ueberhaupt, mit besonderer Betrachtung der schweizerischen Mineralwasser und Badeanstalten, 2 vols. (Ebnat, St.Gallen: Abraham Keller, 1825, 1826); F. B. Zeller, Die Molkenkur in Verbindung der Mineral-Bronnenkur (Würzburg: Etlinger, 1826); H. Rheiner, Das Moosberger oder Heinrichs-Bad im Kanton Appenzell, historisch, chemisch und topographisch beschrieben (St. Gallen: Huber und Compagnie, 1833); Friedrich Garlichs, Über den medizinischen Gebrauch der Milch und der Molke: Eine Inaugural-Abhandlung (Würzburg: Becker, 1837); Vincenz Müller, Specielle Beschreibung der Molkenkur-Anstalten des Königreichs Bayern (Munich: Eigenverlag, 1843); J. J. Strasser, Interlaken im Berner Oberlande als Luft-und Molkenkur-Ort, vom therapeutischen Standpunkte aus betrachtet. (Interlaken: Kurhaus-Verwaltung, 1863); Félix Roubaud, Les Cures de Petit-Lait en Suisse, en Allemagne, dans le Tyrol et la Styrie. (Paris: Adrien Delahaye, 1867).

$30 \quad$ See Barbara Orland, "Le régime suisse du petit lait (18/19 ${ }^{\text {ème }}$ siècle)," in Allaiter. Histoire(s) et cultures d'une pratique, ed. Yasmina Foehr-Janssens and Daniela Solfaroli Camillocci (Turnhout: Brepols Publisher 2022), forthcoming. Eugen Bircher, "Die Molkenkur, ihre Geschichte und geographische Verbreitung. Eine geschichtliche Studie," Schweizerische Medizinische Wochenschrift 39 (1953): 937-41. See more general Jutta Gisela Sperling, ed., Medieval and Renaissance Lactations. Images, Rhetorics, Practices (Burlington: Ashgate, 2013).

31 See Cantor, Reinventing Hippocrates.

32 Georg Heinrich Behr, Zwey Bücher von der Materia Medica, oder vollständige Beschreibung aller und jeder Arzeney-Mittel: Samt beygefügter wohl-eingerichteter und höchst-nutzbarer Therapie (Straßburg: Johannes Beck, 1748), 241-49. 
If the prescription of milk was an at least age-old practice, there is no evidence to believe that people in all European regions or living conditions used milk or its components as a materia medica or even as a food. In the Alpine dairy business, for instance, whey was judged as a negligible waste material, and the use of Schotte (whey) as a remedy was by no means self-evident. Because of its low nutritional value, the residues from the production of butter and cheese were in general not seen as human nutrition, but were merely used as animal feed. In 1706, Johann Jakob Scheuchzer argued in his Beschreibung der Natur-Geschichten des Schweizerlands, while the "exquisite pastures" supply man with milk, butter, and cheese, pigs live from the whey. Only to make use of the remains from making cheese do Swiss dairymen take some pigs to the summer meadows on the Alps. ${ }^{33}$ In other words, there existed no local therapeutic regime or infrastructure that could be adapted to the organization of a whey cure intended to treat foreign people.

Years before the sensational report of the successful recovery of the patient from Zurich, however, another Appenzeller, Laurenz Zellweger (1692-1764), a trained physician and enlightened savant of this region, created the conditions sustaining the proliferation of the use of whey cures in his homeland. ${ }^{34}$ Even at a time when the European elites had not yet learned about the healthy places of canton Appenzell, Zellweger, who lived in the village Trogen, established the goat's whey cure among his urban friends in Zurich and abroad. At least since 1734, some of his closest friends - among them several prominent writers like Johann Jakob Bodmer (1698-1783), Salomon Gessner (1730-1788), or learned physicians like Hans Caspar Hirzel (1725-1803) - visited him occasionally for uplifting conversations, mountain hikes in the Alps, and weeklong whey cures. Zellweger and his friends became known as the Whey Brothers or Whey Society, and there is some evidence that only because of this illustrious group a doctor from abroad got the idea to send a patient into a village of Appenzell. However, when the whey cure business gained momentum, the fame of the Whey Brothers had already faded.

33 Johann Jakob Scheuchzer, Beschreibung der Natur-Geschichten des Schweizerlands, vol. 1, no. 8 (Zurich: Michael Schaufelb.[erger]s. E.[rben] und Christoff Hardmeier, 1706), 30-31.

34 I analyse Zellweger's motivation and scientific context in: Orland, "Le régime suisse du petit lait". See also Heidi Eisenhut, "Gelehrte auf Molkenkur: Laurenz Zellweger und sein Kreis in Trogen," in Heilkunst und schöne Künste: Wechselwirkungen von Medizin, Literatur und bildender Kunst im 18. Jahrhundert, ed. Heidi Eisenhut, Anett Lütteken, and Carsten Zelle (Göttingen: Wallstein, 2011). 


\section{The Pastoral Economy of Gais and Canton Appenzell}

In Appenzell ${ }^{35}$ as everywhere else, the use of milk heavily depended on the economic value of the different dairy products, and this in turn was dependent on the relationship between agriculture and livestock production. Gais, located in the centre of Ausserrhoden, was the only village (among six others of the half-canton) that lies in a mountainous area and possessed different levels of elevation (around 900-130om above sea level). Due to the topographical conditions, a scattered settlement emerged very early and surprised many travellers. While at the end of the 18th century visitors commented on the luscious green of the pastureland, ${ }^{36}$ half a century before they would have found a much more diverse land use. ${ }^{37}$ In a chronicle of 1740 it is written that in Ausserrhoden people planted a lot of grain, wheat, barley, peas, oats and flakes. Beans and other fruits would thrive there too, "so beautiful and perfect, as in the most distinguished countries of Europe."38 Fifty years later, the cereal crop had nearly disappeared; a radical conversion of arable land into meadows and pastures had taken place. Pastures made up the bulk of the habitable surface, and the export of livestock, skins, butter and cheese dominated peasant activities. Grazing management and pastoral economy with summer Alpine farming on higher elevations had replaced all mixed modes of farming. But because there existed no market for animal feed and animals could not be fed through the winter, farmers only partly engaged in cattle breeding. ${ }^{39}$ Rather, they fattened imported and rented livestock over the summer and sold

35 Since 1597, the canton Appenzell was divided into two subdivisions Innerrhoden and Ausserrhoden, as a result of the Swiss Reformation. Gais was one of six Landsgemeinden belonging to the north or half-canton Ausserrhoden, which in many aspects was quite different to its counterpart.

$3^{6}$ See e.g. Heinrich von Malten, Beschreibung aller berühmten Bäder in der Schweiz. Nebst einer allgemeinen Uebersicht der Bäder zweiten Ranges und der unbenutzten Heilquellen (Aarau: Sauerländer, 1830), 21, 48.

37 For the whole paragraph, see Hanspeter Ruesch, Lebensverhältnisse in einem frühen schweizerischen Industriegebiet. Sozialgeschichtliche Studie über die Gemeinden Trogen, Rehetobel, Wald, Gais, Speicher und Wolfhalden des Kantons Appenzell Ausserrhoden im 18. und frühen 19. Jahrhundert, Basler Beiträge zur Geschichtswissenschaft, vol. 139/140 (Basel, Stuttgart: Helbing \& Lichtenhahn, 1979); Walter Schläpfer, Wirtschaftsgeschichte des Kantons Appenzell Ausserrhoden bis 1939 (Herisau: Appenzell-Ausserrhodische Kantonalbank, 1984).

38 Quoted in Ruesch, Lebensverhältnisse, 95 .

39 About the development of cattle breeding in Appenzell, see Matthias Weishaupt: “'Viehveredelung' und 'Rassenzucht'. Die Anfänge der Appenzellischen Viehschauen im 19. Jahrhundert," in Appenzeller Viehschauen, ed. Mäddel Fuchs (St. Gallen: Typotron AG, 1998). 
it in autumn, while farmers, mainly interested in dairy farming, depended on the possibility to manage a year-round stall-feeding. Yet with the exception of those herdsmen who managed about 20 till 24 cows on the Alpine summer meadows, most farms did not have more than two or three cows, which were milked only for self-sufficiency. ${ }^{40}$

However, the transition from agriculture to livestock farming in the second half of the 18th century was not caused by the invention of the whey cure. The main reason lay in the difficult weather conditions of the region. Crop failures have been repeatedly blamed on this phenomenon. ${ }^{41}$ The chroniclers of the Appenzeller Land reported on frosts and droughts, cloudbursts, devastating storms and hailstorms, untimely snowfall, which forced the shepherds with their herds into the valley. Apart from that, livestock farming was based on cattle breeding, oxen, meat and cow milk. Goats played a useful role, less as a poor man's cow than as good feeders on rough Alpine pastures, albeit to a lesser extent than in the neighbouring canton. The available amounts of goat's milk would not have anyway been enough to build a business on it. As Laurenz Zellweger wrote in his Versuch einiger physicalisch und medicinischer Betrachtungen, a book length description of the living conditions in canton Appenzell, there was not even enough cows' milk to serve the needs of the local population. ${ }^{42}$ Whole milk is for the rich, skimmed milk for the poor, he observed. His fellow citizens commonly processed butter from the available milk. Only on feast days, would people not use the available cream for butter production but drink it as so-called Lobmilch. The residual skimmed milk (buttermilk), with the addition of sour whey, was used to make a small and low-fat cheese. But while butter was produced the whole year round, only on their summer meadows on the Alps, Appenzellers produced a fatty cheese from the whole milk. In doing so, the remains (called whey, cheese water or Schotte) were heated several times, depending on the proportion of cheesy matter and acidity. What was left was of little use, the watery part of the milk, the drag-out swill, good enough for the pigs. Appenzellers would only drink this Schotte in the absence of water, Zellweger explained, and they would never

\footnotetext{
40 More on the system of Alpine dairy farming can be found in Orland, "Alpine Milk".

41 Ruesch, Lebensverhältnisse, 86.

42 Between the years 1714 and 1723 , Zellweger drove all over canton Appenzell to familiarize himself with the habits of the people. Laurenz Zellweger, "Versuch einiger physicalisch und medicinischer Betrachtungen," in Abhandlungen der Naturforschenden Gesellschaft in Zürich 2 (Zurich: Heidegger und Compagnie, 1764). In reference to Scheuchzer, he discussed rural commons like Alpine grazing rights, the establishment of rules concerning the access of resources etc. For over ten years, he tried to persuade the herdsmen to let him in on some of their customs, but without success.
} 
consume milk in times of illness, despite being prescribed by a doctor/healer in the cases of specific diseases. Like Galenic medicine advised, they did not appreciate whey. ${ }^{43}$

Visitors, who quite often came from cities, did not gain much insight into the pastoral economy of the Alpine regions. They were mainly delighted by the location. Many praised the fresh green of the hillsides and meadows, the healthy cattle and the local customs. ${ }^{44}$ Equally clueless, outsiders saw the working and living conditions of the local population, recognizing only seldom that most peasant families could not live from the land, but had to earn their living as weavers. ${ }^{45}$ Appenzell Ausserrhoden, from the 1720 on onwards, was known for its linen and cotton spinning, and the fabrication of calico and mousseline, which were mostly exported to Italy, Spain and Germany. "The canvas production in Trogen and Herisau employed almost all the workers of the country, and only those who had not yet decided to leave their fragrant mountain meadow and their Alpine hut inherited from the fathers remained for the care of the cattle and for the cultivation of the Alps," the French Comte de Walsh summed up in $1823 .{ }^{46} \mathrm{He}$ further observed that because of their cottage industry, the Protestant half-canton Ausserrhoden supposed to be much more prosperous than the Catholic Innerrhoden.

This positive impression changed rapidly when Switzerland came under French occupation after 1797. Now the dependency of peasant families on home industry became highly visible. Chroniclers considered the disturbing health developments as direct results of an industrialized way of living and nutrition. If the diet was monotonous even in normal times, one author wrote, alongside with bad weather conditions, followed by crop losses and grain export barriers of foreign countries, it now quickly changed into famine. ${ }^{47}$ Another French gentleman, who travelled through Appenzell in 1798, wrote about the local food crisis:

43 On the medical use of whey, see Orland, "Le régime suisse du petit lait".

44 See e.g. Kronfels, Gais, 35-8; [Johann Heinrich] Ernst, "Nachricht von Gaiss, und von dem daselbst üblichen Gebrauch der Ziegenmolken," Museum der Heilkunde 3 (1795).

45 On Appenzell home industry, see Ruesch, Lebensverhältnisse, 138-40.

46 "Die Leinwandfabrikation in Trogen und Herisau beschäftigte fast alle Arbeitskräfte des Landes, und zur Pflege des Viehs und zur Bewirtschaftung der Alpen blieben nur noch die, welche sich noch nicht entschliessen konnten, ihre duftende Bergwiese und ihre von den Vätern ererbte Alphütte zu verlassen." Quoted in F. Hunziker, "Das Appenzellerland nach früheren französischen Reisebeschreibungen 1750-1840," Appenzellische Jahrbücher 63 (1936): 29 .

47 Hanspeter Ruesch, "Medizinhistorisches aus Appenzell Ausserrhoden (1800-1830)," Gesnerus 36 (1979): 24. 
The number of beggars, especially women and children, is appalling; they come out of their laughing houses with hungry eyes and pleading voice, to gather nettles along the way, from which they live. They are no longer able to procure bread and live almost entirely at the expense of the community and the few affluent people. One distributes oats soups with some meat in them, which are probably donated by the cities (Trogen, Herisau). ${ }^{48}$

In fact, during the years 1770-1772, 1798-1799 and 1816-1818 heavy food crises hit the country. 49

\section{The Development of a Spa Infrastructure}

Any nascent spa tourism would have been affected by such crises, but Gais and its neighbouring villages faced a further problem - their remote location. When around 1760 the legendary healing success with goat's whey drew more patients to Gais, there existed no special infrastructure or transport system. Like any other traveller, the health seekers stayed at the only inn, the Zum Ochsen (the oxen)..$^{50}$ The journey to Gais was arduous and could only be done on foot or on horseback from St. Gallen. It was not until 1784 that a guest dared to travel at breakneck speed on a rocky road in a coach - admired by the villagers as a world event. ${ }^{51}$ As late as 1789 , guests were advised not to go without a guide, as the paths branched and ramified, intersected and suddenly disappeared in the rocks; a labyrinth, which in winter and in bad weather could not be attempted. Around the same time, a traveller circumscribed the rural

48 "Die Anzahl der Bettler, vor allem Frauen und Kinder, ist entsetzlich; sie kommen aus ihren lachenden Häusern mit hungrigem Blick und flehender Stimme, um längs des Weges die Nesseln zu sammeln, von denen sie leben. Sie können sich das Brot nicht mehr verschaffen und leben fast ganz auf Kosten der Gemeinde und der wenig wohlhabenden Leute. Man teilt Hafersuppen mit etwas Fleisch darin aus, die wahrscheinlich von den Städten (Trogen, Herisau) gestiftet werden." Quoted in Hunziker, "Das Appenzellerland", 31.

49 Ruesch, "Medizinhistorisches", 24. The last Swiss food crisis of 1816/1817 is analysed in detail by Daniel Krämer, "Menschen grasten nun mit dem Vieh": Die letzte grosse Hungerkrise der Schweiz 1816/17 (Basel: Schwabe 2015). Krämer describes Appenzell and the eastern part of Switzerland as the most affected regions.

$5^{\circ}$ Still in 1825 , Kronfels described the Ochsen as the most important inn of Gais, although there existed two others. See Kronfels, Gais, 45 .

$5^{1}$ The story is mentioned in the obituary "Altdistriktstatthalter Samuel Heim von Gais, der älteste Landmann," Appenzellische Jahrbücher 4 (1860): 73 . 
seclusion of Gais: "Is it possible, that people from different cantons of Switzerland and southern Germany come here to banish themselves in this sad loneliness? There is no tree, only meadows and pastures, and bare, wildly rugged rocks. This is the darkest place I have ever encountered." ${ }^{52}$

Cut off from the main thoroughfares of the Ancien Regime, Gais needed to develop its own transport and supply system in order to provide accessibility, and this required time. ${ }^{53}$ And because, at the beginning, there was no comfortable accommodation or improved transport, the only unique features that could be highlighted to attract visitor's attention were the inimitable goat's whey and the healthy environment. This discursive strategy seems to have worked quite well, as more guests reportedly began coming to Gais since the ${ }^{176}$ os. ${ }^{54}$ Yet one can estimate that during the first two decades no more than a handful of people stayed for about four to six weeks during summer in Gais. The Ochsen was described as a wooden farmhouse with a dining room, the host family apartment, servant chambers and seven small and simple rooms under the roof for guests. ${ }^{55}$

Then, in 1780, a bad fire promoted innovations. A large part of the village had to be rebuilt; the inn was affected too. Despite economic difficulties, the innkeeper Hans-Ulrich Heim managed to rebuild the tavern larger and more spacious. Now trading under the name of Zum alten Ochsen (the old oxen), it offered space for significantly more guests in 25 comfortable rooms. ${ }^{56}$ The number of Schottatrinker or Schottaherren, as they were called, increased. Spa guests from other Swiss cities (Aarau, Basel, Bern, St. Gallen, etc.) and from the southern part of Germany came, and despite the devastating fire, Gais was able to consolidate its reputation as one of the healthiest whey resorts in Switzerland. Nevertheless, the atmosphere remained relaxed as the village pastor remembered in 1791: "If the spa guests were not too distinguished," one was allowed to sit with sleepyhead, night coat and in slippers at the table. ${ }^{57} \mathrm{But}$

$5^{2} \quad$ "Ist es möglich, dass aus verschiedenen Kantonen der Schweiz und aus Süddeutschland Leute hierher kommen, um sich in diese traurige Einsamkeit zu verbannen? Man sieht keinen Baum, nur Matten und Weiden, und darüber kahle, wild zerklüftete Felsen. Dies ist der düsterste Ort, den ich je angetroffen habe." Quoted in Hunziker, "Das Appenzellerland", 5 .

53 Heim, Die Heilkräfte,183. Hermann Grosser, "Der Fremdenverkehr und seine Entwicklung vom 17. Jahrhundert bis zur Gegenwart im Appenzellerland: unter besonderer Berücksichtigung von Appenzell Innerrhoden," Innerrhoder Geschichtsfreund 22 (1977-1978).

54 There exist only rough data, see ibid.

55 Kronfels, Gais, 41-42.

56 Ibid., 42.

57 "Altdistriktstatthalter Samuel Heim", 73. 
as the number of guests increased from year to year, in 1796 the building was again expanded, and from then on the inn was renamed Kurhaus (spa hotel), and Gais a Molkenkurort (whey spa resort). ${ }^{58}$ Already two years later, however, the thriving whey business was interrupted again. The French army occupied Switzerland, and a division started building the first settlement and headquarter in Gais. Officers and soldiers bordered at the Kurhaus, and although the generals of the French and Austrian armies, who were stationed in Switzerland between 1798 and 1803 (Helvetic Republic), were not interested in a whey cure, they took the opportunity to relax in Gais. Famous guests like Louis Napoleon, who visited Gais with his wife in 1812, or several renowned aristocrats like Pauline of Württemberg or the Markgraf Wilhelm von Baden did their part to increase the fame of Gais. ${ }^{59}$

The business of the innkeeper family, who dominated the health resort, did well for some decades. ${ }^{60}$ In 1791 , Samuel Heim (1764-186o) took over the inn Zum Ochsen from his father Hans-Ulrich Heim (1720-1814), who had begun the whey business and had expanded the house after the fire in 1780 . It was Samuel, who in 1796 converted the inn into a spa centre, famous for its goat products. The herdsmen also played an important role, particularly Anton Josef Inauen (1725-1791), called Schottensepp. During the summer meadow season (between May and August), he brought the fresh whey from the alp Oberer Mesmer to Gais. Due to growing demand, Alpine dairymen from Ebenalp and Meglisalp also supplied goat milk to Gais. Up to the 178 os, the Schottensepp mainly supplied Gais, but the successful expansion of Gais as a health resort encouraged him to introduce whey cures to the nearby village Weissbad as well. ${ }^{61}$ His son Karl Jakob (1755-1811) realized this plan in 1790 and founded the Weissbad Molkenkuranstalt. This new Kurhaus developed into the largest domestic hotel company under the grandson of the Schottensepp, Ignaz Johann Anton Inauen (1794-1864), and housed up to 400 guests from all over Europe during its best days. $^{62}$

\footnotetext{
$58 \quad$ Ibid., 73 .

59 Grosser, "Der Fremdenverkehr", 47.

6o Schläpfer, Wirtschaftsgeschichte, 205-13; Albert Nägeli, "Die Molkenkuren im Appenzellerland," Appenzeller Kalender 220 (1941): n.p.

$61 \quad$ Ibid.

62 The Kurhaus remained under the direction of the Inauen family for five generations up to 1898.
} 
In 1822, when with Johann Heinrich Heim (1802-1876) the next generation took over the Kurhaus, the health resorts of Appenzell were well established, and the businesses consolidated. Accordingly, Johann Heinrich Heim, the son of Samuel, studied medicine and could officiate as the first spa doctor in Gais. With his dissertation of 1824, in which he described the healing power of goat's whey, ${ }^{63}$ the Gaisschottenkur received a scientific legitimation. Heim represented both, the local inventors in a health food, and the knowledge and language of medicine and science. He frequently referred to the extensive use of the mountains as an aesthetic element of the health resort, arguing for the acceptance of a therapeutic landscape. ${ }^{64}$ Finally, he integrated social and environmental considerations; for instance, in the annex to his treatise on the healing power of whey he published some literary works and letters of recommendation of famous guests. ${ }^{65}$

As mentioned at the beginning, recent spa histories have illuminated how traveling was related to the widespread and growing neo-Hippocratic discussions of a therapeutic regimen that involved bathing, exposure to fresh air, personal and domestic hygiene, clothing reform and many other aspects of living. Heim too draw on Hippocrates and explained health and disease by looking at the role of specific agents, namely air, sites, soil and food. He reconfirms that discriminating "unhealthy places" from the opposite, the healthy environment, became an obsession of the elite population in Europe, who sought "to determine what aspects of the environment might be modified to weaken or eliminate their capacity to cause disease." 66 Quite the same fascination with the health aspects of the environment can be found with respect to the Alpine whey cure. First, goat's whey was transformed into a health food, which was not self-evident, as I said before. Whey usually was not used as a human food and only seldom as a laxative. ${ }^{67}$ Not as a precondition but as a result of the whey boom, secondly, the goat became the unique animal of Gais and the

63 See Johann Ulrich Heim, Ueber den medicinischen Gebrauch der Molken. Eine Inaugural-Abhandlung (St. Gallen: Wegelin und Rätzer, 1824).

64 Ibid., 84.

65 Heim, Die Heilkräfte, 132-82.

66 James C. Riley, The Eighteenth-Century Campaign to Avoid Disease (New York: Knopf, 1987), ix.

67 In my opinion, it was probably a coincidence that the success story of 1749 happened using goat's instead of cow's whey. 
Appenzell, and herdsmen developed a flourishing business with the white Appenzell goat breed. ${ }^{68}$

A further innovation was the sweat whey recipe. The drink served by the health resorts of the Appenzell villages should deliberately not be acidic in order to be easier to digest. Heim described the production like this: ${ }^{69}$ A good whey could only be preserved when the goats had already spent fourteen days "in full freedom" on the Alps, where they enjoyed the aromatic Alpine herbs. Basically, it is possible to produce sweet whey in the valley too, he argued, but the best is the milk of mountain goats. Although the goat commonly was seen as an inferior animal, to Heim goat's whey was in fact as good as the cow's whey, only a bit less nutritious. After all, however, this would be a negligible disadvantage, compared to the many benefits of the Alpine sources of this juice.

Most crucially, doctors described whey no longer as the inferior water of milk, but as the juice of herbs. A Dr. Ernst in his enthusiastic report about the Appenzell whey business quoted the renowned physician Samuel Auguste Tissot from Lausanne, who had argued that because milk is nothing else than the more or less unmodified food of the animal, and because the fodder of the Alpine cattle essentially consists of herbs, the whey can rightly be described as a juice of herbs, which is purified and sweetened by the animal body. ${ }^{70}$ Heim, too, repeated perceptions of the mountainous landscape and nature that had been introduced by early naturalists like Conrad Gessner, Johann Jakob Scheuchzer, or Albrecht von Haller. ${ }^{71}$ The fame of mountain products was such a cliché that travellers were surprised not to see cows "walking up to their bellies in grass." Ludwig Wallrath Medicus, a German author who in 1795 wrote his report on Alpine farming, was therefore disappointed to find "just short and rather low grass". ${ }^{72}$ Once doctors had achieved such meanings about the health of the landscape, it was just a small step to argue: "As in summer the fresh herbal juices are already mixed in the milk, and since the milk of mountain plants is always slightly astringent balsamic, it is undoubtedly the most important aid in the medical treatment of the emaciation; it is an

68 See Markus Arbenz et al., Schweizer Ziegen (Winterthur: Birkenhalde-Verlag, 2005), 52-57.

69 Heim, Die Heilkräfte, 3-7.

70 Ernst, "Nachricht von Gaiss", 198.

71 On these perceptions, see Jon Mathieu and Simona Boscani Leoni, eds., Die Alpen! Zur europäischen Wahrnehmungsgeschichte seit der Renaissance - Les Alpes! Pour une histoire de la perception européenne depuis la Renaissance (Bern, Berlin, Bruxelles: Lang, 2005).

72 Ludwig Wallrath Medicus, Bemerkungen über die Alpen-Wirthschaft auf einer Reise durch die Schweiz (Leipzig: Gräff, 1795), 24. 
excellent replacement for power and juice."73 To Heim, the sweetest and best whey, logically, was the one processed by the herdsmen themselves. It seemed not odd to him that the reader should learn in all detail how whey was produced in the Alpine huts of Appenzell, ${ }^{74}$ while, only a few sentences later, he introduced famous names of physicians, starting with Hippocrates, who were said to have prescribed whey as a medicine since the earliest days of humankind. The experience of the past, such was the message, demonstrated that whey was particularly suitable for certain diseases..$^{75}$

It was advantageous that sweet whey was a much tastier drink compared to the product of the earlier dairy tradition, because people were advised to drink a large amount of it. "A whey cure is a long-lasting, gradually increasing and gradually decreasing drinking of the whey towards the end of the treatment," Heim argued. ${ }^{76}$ The drinking was integrated into a rigid daily routine that should underline its therapeutic character. Heim advised his guests to drink about $5^{-7}$ glasses of whey every quarter of an hour, at least 9-12 glasses a day. In between they should stroll over the square in front of the inn, and after this procedure enjoy the rest of the day with relaxation, small walks, and the appreciation of the "good food" of the region. The whey cure lasted a minimum of two to three weeks (for the purification of the body) and six to eight weeks in case of chronic illnesses. For offering warm whey in the morning, the dairyman had to start at midnight with the processing of cheese, which took about two hours. When the whey had reached the boiling point, it was filled in hermetically sealed wooden butts, the so-called Schottatasen, wrapped in cloths, and carried down from the mountain. Leaving the Alp between two and three o'clock in the morning, the shepherd should arrive Gais at six o'clock, where the spa guests gathered to the sound of a bell. ${ }^{77}$

73 "Da nämlich die frischen Kräutersäfte im Sommer in der Milch schon gemischt darin enthalten, und zumal die Milch von Bergpflanzen immer etwas vorstechend balsamisches führt, so ist sie ohne Zweifel das wichtigste Hilfsmittel bei der ärztlichen Behandlung der Auszehrungen; sie leistet ganz vorzüglich Ersatz an Kraft und Saft." J. C. Kottmann, Der Weissenstein. Die Milch- und Molkenkuren, auch Molkenbäder auf dem Jura bei Solothurn (Solothurn: Amiet Lutiger, 1829), 81.

74 Heim, Die Heilkräfte, 4-7.

75 Heim offered a series of indications, but, in the course of time, indications for whey cure treatments in clinical and pharmaceutical handbooks were variable. See e.g. W.[ilhelm] J.[oseph] A.[nton] Werber, Specielle Heilmittellehre: Physikalisch, chemisch, physiologisch, diätetisch und klinisch dargestellt, vol. 1 (Erlangen: Ferdinand Enke, 1859), 93-96.

76 "Eine Molkenkur ist ein längere Zeit anhaltendes, stufenweise steigendes und gegen das Ende der Kur stufenweise fallendes Trinken der Molken." Heim, Die Heilkräfte, 78. Ibid., 103 . 
The whey cure was more than just drinking an Alpine food; descriptions of Gais included leisure activities: "The spa town of Gais is located in a lovely, graceful high mountain valley [...] of that canton, of which Ebel says, 'it resembles an immense English garden, where you find the most beautiful and varied mountain views alternating with the loveliest rural scenes."'78 Heim also recommended shorter walks or hikes to the surrounding mountains. Though one should avoid the highest mountains and those directed to the north, because they provide a disposition to vomit blood. ${ }^{79}$ Heim also dealt with the health value of the atmosphere surrounding Gais. The guest need not worry about too much humidity or fog, he wrote, because "our pure and dry high air absorbs the possible exhalations of our meadows and - because of the few forests in our area and the free entrance and exit of the sunlight and the air - offers a most beautiful level of moisture and dryness of our soil and the atmosphere."80

Over the years, and quite similarly to other tourism initiatives, the Swiss whey cure business brought urban infrastructure to the local population. Bourgeois styles of comfort found their way into rural villages, e.g. on the open square in Gais, where the milk was distributed to the guests, lime trees were planted to provide shadow. Where it was possible (e.g. in Heinrichsbad) local authorities combined mineral baths with milk cures and whey bathing, or they extended their therapeutic offers with herb treatments, mudpacks etc. ${ }^{81}$ A good example is the so-called cowshed-cure. Because most bath buildings were situated near farmhouses, guests were advised to stay for hours in cowshed rooms. In a cowshed, for several hours the patient should inhale the animal breath and body vapour of the cattle. The ammonia gases from urine were advertised as a balsam for infected lungs. ${ }^{82}$

Further on, the Molken-Gewerbler of Appenzell sold a plethora of medical or health products from whey, among them serum lactis dulce (sweet whey for children, produced with rennet and beaten egg white), serum lactis acidulum (sour whey, coagulated with citron or creme tartaris), serum lactis vinosum (with white wine), serum lactis aluminosum (coagulated by alum, prescribed

$7^{8}$ "Der Kurort Gais liegt in einem lieblichen, anmutigen, mit grünen Hügeln umgebenen, vom Rothbach durchflossenen, hohen Bergtale jenes Kantons, von dem Ebel sagt: 'er gleichen einem unermesslichen englischen Garten, wo man die schönsten und mannigfaltigsten Gebirgsaussichten mit den lieblichsten ländlichen Szenen abwechseln sieht." Ibid., 94. Heim refers to Johann Gottfried Ebel (1764-1830), a physician who travelled extensively through the Alps and published geological treatises.

79 Kottmann, Der Weissenstein, 129.

8o Heim, Die Heilkräfte, 115 .

81 Rheiner, Das Moosberger-oder Heinrichs-Bad.

82 Ibid., 29. 
in case of dysenterie, gonorrhoea, or white flux), serum lactis tamarindinatum (with tamarind), petit-lait en poudre as a first-aid kit (with gummi arabicum, milk sugar and milk protein), serum lactis antiscorbuticum (with several herbs). ${ }^{83}$

\section{Visitors' Judgement}

How did the travellers, who underwent extensive efforts and spent large amounts of money to frequent spas for medical purposes, respond? What justified the success of mountainous whey producers? In the words of the early 19th century novelist Ulrich Hegner, "Whey could have been processed at home, where we have enough cows and fatty food." 84 What then was the advantage of visiting Gais?

Ulrich Hegner (1759-1840), who had studied medicine in Strasbourg from 1776-1781, lived in Winterthur and Zurich, when he wrote and published his popular novel about the Swiss whey cure in the year 1812. The main figure was a colonel from the northern part of Germany, a hypochondriac and sceptic, who undertook the long journey to Switzerland with his niece. The young woman is characterized as a romantic person, who has fallen in love with the people and nature of the host country. In the form of letters or talks with other visitors of Gais (one French noblemen, an Englishman, a Swiss vicar) the author lets his readers recognize how mountains and people rejuvenated him. The whey cure itself, however, is partly ironically exaggerated, partly questioned in its medical effect. Obviously, the colonel doubted the effect of the health food, instead was touched by the social and natural environment. The assumed medicinal properties of the whey were insignificant, and in the end, the narrative judged social contacts more beneficial to body and mind than air and food.

Evaluation thus went further than medical reviews. Hegner offered a sophisticated social analysis, arguing that most travellers would regard the purpose of wellbeing and social contact in the same way as medical claims or discussions about physical conditions and diseases. ${ }^{85}$ To physicians, in contrast, the virtues of goat's whey were debated by an increasing number of chemical and medical

\footnotetext{
83 See Garlichs, Über den medizinischen Gebrauch, 21-24.

84 Ulrich Hegner, Die Molkenkur (Zurich: Orell Füssli, 1812), 9.

85 Although there existed many differences among spas, this is one of the general results of the examination of spa histories. See John K. Walton, "Health, Sociability, Politics and Culture. Spas and History: An Overview," in Mineral Springs Resorts in Global Perspective. Spa Histories, ed. John K. Walton (London: Routledge 2014).
} 
experiments undertaken since about $1830 .{ }^{86}$ Scientific discourses dealt with issues like whey drinking as a treatment against chest affections, lung diseases or consumption. ${ }^{87}$ Was whey itself the active substance or the spicy herbs of the Alps? Was living in the "Swiss" Alps healthier than living in other landscapes or mountains? Did residents in hill countries get the same diseases as people, plants, or animals in the lowlands? No easy questions, argued the British doctor John Macpherson (1817-189o), because scientific parameters do not evaluate national differences. "Alpine climates have been divided somewhat artificially into various zones, and their effects have been characterized as tonic and vivifying, tonic and exciting, \&c.; but such divisions are at best dependent on latitude and on local influences." ${ }^{\prime 88}$

Travellers often described certain effects of the air at higher elevations, such as accelerated action of the heart, nose or ear bleeding, headaches, and "incapacity for exertion." ${ }^{89}$ Nervous excitement or sleeplessness and other unpleasant effects made the stay in Switzerland a contra-indication. But although this might happen particularly in the beginning of a stay in the mountains, in most cases, however, the body soon gets accustomed to the change, Macpherson argued. Beside this, changes of barometric pressure and of the moisture of the atmosphere "are beneficial in giving the system alternate periods of excitement and of rest." 90 From a physiological point of view, he summarized his results, there was no clear indication that a stay in the mountains was beneficial or harmful.

Contrary to all proverbial shepherd natures, travellers confessed that the health conditions of the local population had to be assessed differently. "It is by no means easy to get very satisfactory evidence as to the health of residents in hill countries," Macpherson further reflected. In the lower parts of the Swiss mountains, dysentery, diarrhoea and low fevers seemed to be quite common. On the other hand, there had to be no doubt "that certain elevated spots enjoy a considerable amount of immunity from lung tuberculosis,"91 while at other places one observed a good deal of phthisis and rheumatism, particularly in

86 See e.g. Christian Heinrich Ernst Bischoff, Die Lehre von den chemischen Heilmitteln oder Handbuch der Arzneimittellehre: als Grundlage für Vorlesungen und zum Gebrauche praktischer Aerzte und Wundärzte. Enthaltend des Verfassers fernere wissenschafftliche Beyträge nebst den neueren Erwerbnissen und materiellen Bereicherungen der Arzneimittel-Lehre, auch das vollständige Register über das ganze Werk, vol. 4 (Bonn: Eduard Weber, 1834), 49o.

87 Dr. Mich. Karner, "Die Molkenkur in ihrer Beziehung zur Lungentuberkulose," Froriep's Notizen aus dem Gebiete der Natur- und Heilkunde 2 (1858).

88 Macpherson, The Baths and Wells, 36.

89 Ibid., 33 .

$90 \quad$ Ibid., 35 .

91 Ibid., 37 . 
Gais. From all this, he did not want to conclude that it is an unsuitable place to any consumptive patient. "I would only say that mere elevation is no sure test of the healthiness of a place."92 Similar critical judgments about the health value of whey accumulated over the years. Many more voices than at the beginning of the whey boom mentioned the unpleasant taste of goat's whey, a fluid "with a mawkish taste" 93 or considered it an unhealthy therapy anyway.

Needless to say, chemists of the late 18th and early 19th century supported such views by their analysis of the specific ingredients of milk in general, and whey in particular. Their key objective was the improvement of cheese making, yet with respect to waters and other health drinks, it very soon became most common to class them according to their chemical composition. "The geo-gnostic character of the soil, from which the mineral springs as well as the diets owe their origin" can be either analyzed by their sensory properties. Even better is chemical analysis, because it "permits as a rule correct conclusions as to content and effects" of any kind of substance. ${ }^{94}$

However, the more spa doctors asked for scientific investigations, the more they undermined the environmental health claims. One recurrent argument runs through the medical literature of the 19th century, and this is the accusation of a pseudo or non-scientific approach of the health resorts. Rules are required for the evaluation of the milk or whey cure claimed Herrmann Lebert, Professor of Medicine at the University of Breslau, in 1869. There are too many apodictic and not proven opinions about the properties of whey. ${ }^{95}$ Whether the cure is effective or not, is just a question of empirical experience, he criticized. The supposedly useful and beneficial influence of the aromatic Alpine herbs on the healing power of the whey he could not validate a scientific knowledge. Most practitioners in health resorts were not even trained physicians, and the "lack of knowledge about the chemical-physiological aspects of the whey is disturbing." ${ }^{\prime 96}$

\footnotetext{
$92 \quad$ Ibid.

93 Ibid., 346.

94 Gabriel Rüsch, Anleitung zu dem richtigen Gebrauche der Bade- und Trinkcuren ueberhaupt, mit besonderer Betrachtung der schweizerischen Mineralwasser und Badeanstalten, vol. 1 (Ebnat, St.Gallen: Abraham Keller, 1825), 270-79.

95 Herrmann Lebert, Ueber Milch- und Molkenkuren und über ländliche Kurorte für unbemittelte Brustkranke (Berlin: August Hirschwald, 1869).

96 Ibid., 11.
} 
But what kind of knowledge had chemistry to offer? A chemically informed explanation of the whey cure went like this:

Whey [...] is recommended theoretically, as supplying to the blood only non-nitrogenous elements, the nitrogenous casein and the fat being excluded; the notion is, that the constitution of the fluids and tissues of the body is altered and improved by the salts and milk-sugar which it contains, while the nitrogenous elements are withheld. But these theoretical ideas are of no real importance, as long as all patients drinking whey at the same time use a diet in which there is an abundance of nitrogenous or protein substances; some have attributed special virtues to the small quantity of the salts of potass present in whey. ${ }^{97}$

Reflecting the research so far, Macpherson concluded that milk and whey cures could be obtained almost everywhere. From a chemical point of view, there existed no serious difference between the lowland and mountainous products.

Scientific knowledge, in fact, delivered no clear data that would meet the practical needs of the visitors of whey spas. One experienced doctor concluded from this "that, by the same token, the educated reader will always give preference to a place which gives him pleasant memories or presents ample material for comparisons of the old and new times, and for pleasant conversation."98 Science so to say complicated existing ways of evaluation, or the muddling towards understandings. Medico-chemical explanations confronted entrepreneurs with a completely new style of thinking, because the health value of milk like of any other organic substance changed its meaning. The technological epistemology of the modern sciences presupposed a scientifically standardized fluid. The then dominating environmental perspective, in contrast, valued the local impact of flora and fauna.

97 Macpherson, The Baths and Wells, 321.

98 "dass der gebildete Leser unter übrigens gleichen Umständen immer einem Orte den Vorzug geben wird, der ihm angenehme Erinnerungen erregt oder reichlichen Stoff zu Vergleichungen aus der alten und neuen Zeit und zu angenehmer Unterhaltung darbietet." Rüsch, Anleitung, XII. 
Almost every spa promotion of the 19th century was accompanied by an appeal to this scientific style of thinking. At first it wasn't harmful to business either. The Swiss whey cure morphed from a local to a nationwide health business, from a place that had begun its business with an environmental advantage. And yet, around the 1840s, the reference to alpine nature slowly lost its power of conviction. To Hermann Lebert it was not only the lack of science but sometimes the scientific investigation itself that damaged the business. Asserted medicinal benefits alternated too often and in the worst case even contradicted each other. Over time, Lebert observed, the Appenzeller had varied their arguments substantially. At the beginning, the effluent effect of whey was decisive, which was easily attainable by the large quantities people had to drink. Later, a resolving effect was emphasized, which, however, was a very vague and elastic concept. And when the whole world spoke of cells, whey was supposed to dissolve and remove abnormal cell formation. ${ }^{99}$ Some praised the mild-nourishing effect of whey and were happy, if a sick patient during the cure gained a bit weight. Others, in turn, emphasized the secretion-promoting effect of whey. The consequence of this rebuttal of the popular agency of whey was that it invalidated the notion of whey as a medicine. Moreover, it questioned the credibility of the public understanding of nature insofar as it reduced the health benefits to a negotiable commodity.

Whey lost its medical importance and to Lebert the whey cure remained nothing more than a fashion that sooner or later would lose its lovers. It was highly striking, he went on, that only German-speaking regions established a whey cure business, not France, Italy, England, or the United States. Ignorance could not have been the cause, he grumbled. ${ }^{100}$ The decisive reason why Switzerland was so successful, he concluded, must have been the climatic element, while almost all other German health resorts mixed whey with mineral water, and sold it together with baths, inhalations and other health care offers.

There is no solid data on the development of the whey cure business from the late 18 th century to the end of the 19th century. It is, moreover, difficult to answer the question when exactly the Swiss whey cure reached its high point in Appenzell and beyond. The general perception is that until the 186 os, businesses went quite well and thereafter went into decline, or at least stagnated.

99 Lebert, Ueber Milch- und Molkenkuren, 66.

$100 \quad$ Ibid., 68. 
At that time, the increasing railway infrastructure accelerated structural change, but so far no study has quantified these effects in the Swiss context. Certainly, the railway expansion promoted tourism and leisure activities, but it also increased competition between the regions and locations. For instance, with respect to pulmonary diseases locations like Davos and St. Moritz and Grison in general became much more fashionable, particularly because of their higher altitudes. ${ }^{101}$

Changes in curative regimes might also have been responsible for a slow decline of the whey cure. In the early days of the late 18th century, when people went to Gais, it was for treatment. Around the 183 os patients and invalids were already in a minority; Gais and its neighbouring villages had become locations of health tourism, with sociability and respectability, advertising the term Geiß-Schotten-Kur as a Swiss symbol. Fifty years later, the term had disappeared, displaced by the general treatment named whey cure (with only seldom mentioning goat's whey). ${ }^{102}$ Recognizably the business had expanded, fragmented and diversified. The famous traveller's guide by Karl Baedeker emphasized in its edition of 1873 that the Weissenstein nearby Soleure had become one of the most frequented mountains for whey cures, but one could also find establishments near Zurich in Rapperswil, Einsiedeln, at the Rigi, in Interlaken or Churwalden. ${ }^{103}$ The Appenzeller whey cure, meanwhile also whey bath, had become much less distinctive; it was just one spa among a range of many other. And not to forget, it remained a seasonal business of at least three months in the summer. Unlike spa waters whey could not be bottled for home use; the whey cure required a residential stay.

To sum up, while during the second half of the 18 th century the procedure of the whey cure became an emblematic marker of the healthy environment of the Alps, during the 19th century the cure symbolized a new direction that medical practice was pursuing. It changed from its task of healing the ill to becoming a tool of prevention, wellbeing, and sociability. Although health was no longer only perceived as a day-to-day experience but as a merit "good" that must and could be processed and purchased, the place where to buy the

\footnotetext{
101 Sigismond Jaccoud, The Curability and Treatment of Pulmonary Phthisis, trans. Montagu Lubbock (New York: Appleton and Company, 1885), 334.

102 Spa handbooks of the 1870 illuminate that there was scarcely a bathing resort or a spa, which did not provide the possibility of drinking whey. Julius Braun, On the Curative Effects of Baths and Waters Being a Handbook to the Spas of Europe, an Abridged Translation with Notes by Hermann Weber (London: Smith, Elder, \& Co, 1875), 439.

103 Karl Baedeker, Switzerland: And the Adjacent Portions of Italy, Savoy, and the Tyrol. Handbook for Travellers. Sixth Edition, Revised and Augmented (Coblenz, Leipzig: Karl Baedeker, 1873), 11.
} 
treatment started to play a minor role. The close link between landscape and health became looser, or better to say, it had to be refashioned again. The story of Gais and its invention of the Gaisschottenkur were transmuted into a marketing concept that used inherited stories and tales, which people told about successful therapies. The healthy character of the mountains milk remained slightly more than symbolic capital.

\section{Acknowledgement}

This paper is based on research supported by the Family Larsson-Rosenquist Foundation.

\section{Bibliography}

\section{Printed Sources}

"Altdistriktstatthalter Samuel Heim von Gais, der älteste Landmann." Appenzellische Jahrbücher 4 (1860): 69-80.

Baedeker, Karl. Switzerland: And the Adjacent Portions of Italy, Savoy, and the Tyrol. Handbook for Travellers. Sixth Edition, Revised and Augmented. Coblenz, Leipzig: Karl Baedeker, 1873 .

Behr, Georg Heinrich. Zwey Bücher von der Materia Medica, oder vollständige Beschreibung aller und jeder Arzeney-Mittel: Samt beygefïgter wohl-eingerichteter und höchst-nutzbarer Therapie. Straßburg: Johannes Beck, 1748.

Bischoff, Christian Heinrich Ernst. Die Lehre von den chemischen Heilmitteln oder Handbuch der Arzneimittellehre: als Grundlage für Vorlesungen und zum Gebrauche praktischer Aerzte und Wundärzte. Enthaltend des Verfassers fernere wissenschafftliche Beyträge nebst den neueren Erwerbnissen und materiellen Bereicherungen der Arzneimittel-Lehre, auch das vollständige Register über das ganze Werk, vol. 4. Bonn: Eduard Weber, 1834.

Braun, Julius. On the Curative Effects of Baths and Waters Being a Handbook to the Spas of Europe, an Abridged Translation with Notes by Hermann Weber. London: Smith, Elder, \& Co, 1875 .

Ernst, [Johann Heinrich]. "Nachricht von Gaiss, und von dem daselbst üblichen Gebrauch der Ziegenmolken." Museum der Heilkunde 3 (1795): 196-208.

Garlichs, Friedrich. Über den medizinischen Gebrauch der Milch und der Molke: Eine Inaugural-Abhandlung. Würzburg: Becker, 1837.

Hegner, Ulrich. Die Molkenkur. Zurich: Orell Füssli, 1812. 
Heim, Johann Heinrich. Die Heilkräfte der Alpenziegen-Molken und der Molkenkurort Gais. Zurich: Schultheß, 1844.

Heim, Johann Heinrich. Ueber den medicinischen Gebrauch der Molken. Eine InauguralAbhandlung. St. Gallen: Wegelin und Rätzer, 1824.

Hippocrates. On Airs, Waters, and Places. Translated by Francis Adams. Last modified July 3, 2018. http://classics.mit.edu//Hippocrates/airwatpl.html, accessed on 3 July 2018.

Jaccoud, Sigismond. The Curability and Treatment of Pulmonary Phthisis. Translated by Montagu Lubbock, New York: Appleton and Company, 1885.

Karner, Dr. Mich. “Die Molkenkur in ihrer Beziehung zur Lungentuberkulose.” Froriep's Notizen aus dem Gebiete der Natur- und Heilkunde 2 (1858): 215-19.

Kottmann, J[ohann] C[arl]. Der Weissenstein. Die Milch- und Molkenkuren, auch Molkenbäder auf dem Jura bei Solothurn. Solothurn: Amiet_Lutiger, 1829.

Kronfels, Fr.[iedrich] K. v. Gais, Weisbad und die Molkenkuren im Canton Appenzell. Constance: W. Wallis, 1826.

Lebert, Herrmann. Ueber Milch- und Molkenkuren und über ländliche Kurorte für unbemittelte Brustkranke. Berlin: August Hirschwald, 1869.

Macpherson, John. The Baths and Wells of Europe: Their Action and Uses, with Hints on Change of Air and Diet Cures. London: Macmillan and Co, 1869.

Malten, Heinrich von. Beschreibung aller berühmten Bäder in der Schweiz. Nebst einer allgemeinen Uebersicht der Bäder zweiten Ranges und der unbenutzten Heilquellen. Aarau: Sauerländer, 183 .

Medicus, Ludwig Wallrath. Bemerkungen über die Alpen-Wirthschaft auf einer Reise durch die Schweiz. Leipzig: Gräff, 1795.

Morgenblatt für gebildete Leser, no. 3, January 3, 1849, 5 .

Müller, Vincenz. Specielle Beschreibung der Molkenkur-Anstalten des Königreichs Bayern. Munich: Eigenverlag, 1843.

Roubaud, Félix. Les Cures de Petit-Lait en Suisse, en Allemagne, dans le Tyrol et la Styrie. Paris: Adrien Delahaye, 1867.

Rheiner, H. Das Moosberger oder Heinrichs-Bad im Kanton Appenzell, historisch, chemisch und topographisch beschrieben. St. Gallen: Huber und Compagnie, 1833.

Rüsch, Gabriel. Anleitung zu dem richtigen Gebrauche der Bade- und Trinkcuren ueberhaupt, mit besonderer Betrachtung der schweizerischen Mineralwasser und Badeanstalten, 2 vols. Ebnat, St.Gallen: Abraham Keller, 1825, 1826.

Rüsch, Gabriel. Heiden und seine Molkenkuranstalt im Freihof. Trogen: Schläpfer, 1854. Scheuchzer, Johann Jakob. Beschreibung der Natur-Geschichten des Schweizerlands, vol 1, no. 8. Zurich: Michael Schaufelb.[erger]s. E.[rben] und Christoff Hardmeier, 1706. Shoberl, Frederic. The World in Miniature. Switzerland, Containing a Description of the Characters, Manners, Customs, Diversions, Dress \&c. of the People of that Country in General, and of the Inhabitants of the twenty-two Cantons in particular. London: R. Ackermann, 1827 . 
Strasser, J. J. Interlaken im Berner Oberlande als Luft- und Molkenkur-Ort, vom therapeutischen Standpunkte aus betrachtet. Interlaken: Kurhaus-Verwaltung, 1863.

Weber, Herman. "Notes on the Climate of the Swiss Alps, and on some of their Health Resorts and Spas." The Dublin Quarterly Journal of Medical Science 37, no. 2 (1864): $333-64$.

Werber, W.[ilhelm] J.[oseph] A.[nton]. Specielle Heilmittellehre:Physikalisch, chemisch, physiologisch, diätetisch und klinisch dargestellt, vol. 1. Erlangen: Ferdinand Enke, 1859.

Zeller, F. B. Die Molkenkur in Verbindung der Mineral-Bronnenkur. Würzburg: Etlinger, 1826.

Zellweger, Laurenz. "Versuch einiger physicalisch und medicinischer Betrachtungen." In Abhandlungen der Naturforschenden Gesellschaft in Zürich 2, 309-6o. Zurich: Heidegger und Compagnie, 1764.

\section{Literature}

Association Internationale pour l'Histoire des Alpes, ed. Histoire des Alpes. Zurich: Chronos, 1996-2018.

Arbenz, Markus et al. Schweizer Ziegen. Winterthur: Birkenhalde-Verlag, 2005.

Bätzing, Werner. Die Alpen. Geschichte und Zukunft einer europäischen Kulturlandschaft, 4th. rev. ed. Munich: Beck, 2015.

Barton, Susan R. Healthy Living in the Alps: The Origins of Winter Tourism in Switzerland, 1860-1914. Manchester: Manchester University Press, 2008.

Beattie, Andrew. The Alps: A Cultural History. Oxford: Oxford University Press, 2006.

Bircher, Eugen. "Die Molkenkur, ihre Geschichte und geographische Verbreitung. Eine geschichtliche Studie." Schweizerische Medizinische Wochenschrift 39 (1953): 937-53.

Boscani Leoni, Simona. “Tra Zurigo e le Alpi: le 'Lettres des Grisons' di Johann Jakob Scheuchzer (1672-1733). Dinamiche della comunicazione erudita all'inizio del Settecento." In Die Alpen! Zur europäischen Wahrnehmungsgeschichte seit der Renaissance - Les Alpes! Pour une histoire de la perception européenne depuis la Renaissance, edited by Jon Mathieu and Simona Boscani Leoni, 157-171. Bern: Peter Lang, 2005.

Boscani Leoni, Simona, ed. Wissenschaft - Berge - Ideologien.Johann Jakob Scheuchzer (1672-1733) und die frühneuzeitliche Naturforschung - Scienza - montagna - ideologie. Johann Jakob Scheuchzer (1672-1733) e la ricerca naturalistica in epoca moderna. Basel: Schwabe, 2010.

Cantor, David, ed. Reinventing Hippocrates. Ashgate: Aldershot, 2002.

Cavallo, Sandra and Tessa Storey, eds. Conserving Health in Early Modern Culture. Bodies and Environments in Italy and England. Manchester: Manchester University Press, 2017.

Classen, Albrecht, ed. Bodily and Spiritual Hygiene in Medieval and Early Modern Literature: Explorations of Textual Presentations of Filth and Water. Berlin, Boston: De Gruyter, 2017. 
Classen, Albrecht. "Introduction: Bathing, Health Care, Medicine, and Water in the Middle Ages and Early Modern Age." In Bodily and Spiritual Hygiene in Medieval and Early Modern Literature: Explorations of Textual Presentations of Filth and Water, edited by Albrecht Classen, 1-87. Berlin, Boston: De Gruyter, 2017.

Coley, Noel G. "Physicians, Chemists and the Analysis of Mineral Waters: 'The most difficult part of Chemistry'. In The Medical History of Water and Spas, edited by Roy Porter, 56-66. London: Wellcome Institute for the History of Medicine, 1990.

Eddy, Matthew Daniel. "The Sparkling Nectar of Spas, or, Mineral Water as a Medically Commodifiable Material in the Province, 1770-1805." In Materials and Expertise in Early Modern Europe. Between Market and Laboratory, edited by Ursula Klein and Emma C. Spary, 198-224. Chicago, London: The University of Chicago Press, 2010.

Eisenhut, Heidi. "Gelehrte auf Molkenkur. Laurenz Zellweger und sein Kreis in Trogen." In Heilkunst und schöne Künste. Wechselwirkungen von Medizin, Literatur und bildender Kunst im 18. Jahrhundert, edited by Heidi Eisenhut, Anett Lütteken, and Carsten Zelle, 271-302. Göttingen: Wallstein, 2011.

Esser, Raingard and Thomas Fuchs, eds. Bäder und Kuren in der Aufklärung: Medizinaldiskurs und Freizeitvergnügen. Berlin: Berliner Wissenschafts-Verlag, 2003. Flubacher, Silvia. "Alpen-Tiere. Lokale Wissenswelten in der schweizerischen Naturgeschichtsschreibung." In Wissenschaftsgeschichte und Geschichte des Wissens im Dialog - Connecting Science and Knowledge: Schauplätze der Forschung, edited by Kaspar von Greyerz, Silvia Flubacher, and Philipp Senn, 347-74. Göttingen: V\&R unipress, 2013.

Fürbeth, Frank. "Adaptionen gelehrten Wissens für laikale Zwecke in der Bäderheilkunde der frühen Neuzeit." In Wissenschaftsgeschichte und Geschichte des Wissens im Dialog - Connecting Science and Knowledge: Schauplätze der Forschung, edited by Kaspar von Greyerz, Silvia Flubacher, and Philipp Senn, 211-30. Göttingen: V\&R unipress, 2013.

Gebhard, Ulrich and Thomas Kistemann, eds. Landschaft, Identität und Gesundheit. Zum Konzept der therapeutischen Landschaften. Wiesbaden: Springer VS, 2016.

Grosser, Hermann. "Der Fremdenverkehr und seine Entwicklung vom 17. Jahrhundert bis zur Gegenwart im Appenzellerland: unter besonderer Berücksichtigung von Appenzell Innerrhoden." Innerrhoder Geschichtsfreund 22 (1977-1978): 45-6o.

Habrich, Christa. "Medizin- und naturwissenschaftshistorische Aspekte der Alpen als Heilungs- und Erholungsraum." In Die Alpen als Heilungs- und Erholungsraum. Historikertagung in Meran - Le alpi: luogo di cura e riposo: convegno storico a Merano: 19.-21.X.1988, edited by Josef Nössing, 11-34. Bozen: Verlagsanstalt Athesia, 1994.

Hofmann, Heini. Gesundheits-Mythos St. Moritz. Sauerwasser, Gebirgssonne, Höhenklima. St. Moritz: Montabella-Verlag, 2011.

Hunziker, F. "Das Appenzellerland nach früheren französischen Reisebeschreibungen 1750-1840.” Appenzellische Jahrbücher 63 (1936): 1-36. 
Jankovic, Vladimir. "The Last Resort: A British Perspective on the Medical South, 18151870." Journal of Intercultural Studies 27, no. 3 (2006), 271-98.

Krämer, Daniel. "Menschen grasten nun mit dem Vieh.”: Die letzte grosse Hungerkrise der Schweiz 1816/17. Basel: Schwabe 2015.

Lotz-Heumann, Ute. "Finding a Cure. Representations of Holy Wells and Healing Waters in Early Modern Germany." In Wissenschaftsgeschichte und Geschichte des Wissens im Dialog - Connecting Science and Knowledge: Schauplätze der Forschung, edited by Kaspar von Greyerz, Silvia Flubacher, and Philipp Senn, 233-54. Göttingen: V\&R unipress, 2013.

Mathieu, Jon and Simona Boscani Leoni, eds. Die Alpen! Zur europäischen Wahrnehmungsgeschichte seit der Renaissance - Les Alpes! Pour une histoire de la perception européenne depuis la Renaissance. Bern, Berlin, Bruxelles: Lang, 2005.

Mathieu, Jon. Eine Agrargeschichte der inneren Alpen. Graubünden, Tessin, Wallis 1500180o. Zurich: Chronos-Verlag, 1992.

Mathieu, Jon, Norman Backhaus, Katja Hürlimann, and Matthias Bürgi, eds. Geschichte der Landschaft in der Schweiz. Von der Eiszeit bis zur Gegenwart. Zurich: Orell Füssli, 2016.

Nägeli, Albert. "Die Molkenkuren im Appenzellerland." Appenzeller Kalender 220 (1941): n.p.

Neswald, Elizabeth. "Asserting Medical Identities in Mid-Nineteenth Century Ireland: the Case of the Water Cure in Cork." In Science and Technology in Nineteenth-Century Ireland, edited by Janina Adelman and Eadaoin Agnew, 32-47. Dublin: Four Courts Press, 2010.

Orland, Barbara. "Alpine Milk: Dairy Farming as a Pre-modern Strategy of Land Use." Environment and History 3 (2004): 327-64.

Orland, Barbara. "Le régime suisse du petit lait (18/19ème siècle)," in Allaiter. Histoire(s) et cultures d'une pratique, edited by Yasmina Foehr-Janssens and Daniela Solfaroli Camillocci. Turnhout: Brepols Publisher 2022 (forthcoming).

Palmer, Richard. "In this our lightye and learned tyme': Italian Baths in the Era of the Renaissance." In The Medical History of Water and Spas, edited by Roy Porter, 14-22. London: Wellcome Institute for the History of Medicine, 1990.

Riley, James C. The eighteenth-century campaign to avoid disease. New York: Knopf, 1987.

Reichler, Claude. La montagne réinventée. Géographes, naturalistes et sociétés (XVIII $X X^{e}$ siècles) - Reinventing Mountain Areas: Geographers, Naturalists and Society (18th-2oth centuries). Grenoble: Revue de géographie alpine (Institut de Géographie Alpine), 1994.

Reichler, Claude. La découverte des Alpes et la question du paysage. Chêne-Bourg: Georg, 2002. 
Ruesch, Hanspeter. Lebensverhältnisse in einem frühen schweizerischen Industriegebiet. Sozialgeschichtliche Studie über die Gemeinden Trogen, Rehetobel, Wald, Gais, Speicher und Wolfhalden des Kantons Appenzell Ausserrhoden im 18. und frühen 19. Jahrhundert, Basler Beiträge zur Geschichtswissenschaft, vol. 139/140. Basel, Stuttgart: Helbing \& Lichtenhahn, 1979.

Ruesch, Hanspeter. "Medizinhistorisches aus Appenzell Ausserrhoden (1800-1830)." Gesnerus 36 (1979): 21-34.

Sargent, Frederick II. Hippocratic Heritage: a History of Ideas about Weather and Human Health. New York: Pergamon Press, 1982.

Schläpfer, Walter. Wirtschaftsgeschichte des Kantons Appenzell Ausserrhoden bis 1939. Herisau: Appenzell-Ausserrhodische Kantonalbank, 1984.

Schürer, Christian. Der Traum von Heilung. Eine Geschichte der Höhenkur zur Behandlung der Lungentuberkulose. Baden: hier + jetzt, 2017.

Senn, Philipp. "Forscher vor Ort. Johann Jakob Scheuchzer (1672-1733), Bündner Gönner und die Balneologie." In Wissenschaftsgeschichte und Geschichte des Wissens im Dialog - Connecting Science and Knowledge: Schauplätze der Forschung, edited by Kaspar von Greyerz, Silvia Flubacher, and Philipp Senn, 255-92. Göttingen: V\&R unipress, 2013 .

Sperling, Jutta Gisela, ed. Medieval and Renaissance Lactations. Images, Rhetorics, Practices. Burlington: Ashgate, 2013.

Tissot, Laurent. "From Alpine Tourism to the 'Alpinization' of Tourism." In Touring Beyond the Nation: A Transnational Approach to European Tourism History, edited by Eric G. E. Zuelow, 59-78. Farnham, Uk: Ashgate, 2011.

Treichler, Hans Peter. "Molken, Milch und Traubenberge. Neue Ansätze im Kurwesen." In Zauberberge. Die Schweiz als Kraftraum und Sanatorium, edited by Felix Graf and Eberhard Wolff, 49-52. Baden: hier + jetzt, 2010.

Vaj, Daniela. “La géographie médicale et l'immunité phtisique des altitudes aux sources d'une hypothèse thérapeutique $=[$ Medical Geography and Phthisic Immunity in the High Altitudes : the Origins of a Therapeutic Hypothesis]." Revue de géographie alpine-Journal of Alpine Research 93, no. 1 (2005): 21-33.

Vaj, Daniela. "Le Bon air des Alpes et le développement des stations climatiques d'altitude." In Bon air des Alpes: des stations climatiques au tourisme de bien-être: actes du colloque, Sierre, 7-8.10.2004 - Die gute Alpenluft: von den Luftkurorten zum Wellnesstourismus: Tagungsband, Siders, 7.-8.10.2004, edited by HES-SO Valais, 53-65. Sierre: HEs-so Valais, 2007.

Vogler, Werner. "Heilbäder in den Alpen im Spätmittelalter und in der Renaissance am Beispiel von Pfäfers." In Die Alpen als Heilungs- und Erholungsraum. Historikertagung in Meran - Le alpi: luogo di cura e riposo: convegno storico a Merano: 19.-21.X.1988, edited by Josef Nössing, 137-56. Bozen: Verlagsanstalt Athesia, 1994. 
Walsham, Alexandra. The Reformation of the Landscape. Religion, Identity, and Memory in Early Modern Britain and Ireland. Oxford: Oxford University Press, 2011.

Walton, John K. "Health, Sociability, Politics and Culture. Spas and History: An Overview." In Mineral Springs Resorts in Global Perspective. Spa Histories, edited by John K. Walton, 1-14.

Walton, John K., ed. Mineral Springs Resorts in Global Perspective. Spa Histories. London, New York: Routledge 2014.

Weishaupt, Matthias. “Viehveredelung' und 'Rassenzucht'. Die Anfänge der Appenzellischen Viehschauen im 19. Jahrhundert." In Appenzeller Viehschauen, edited by Mäddel Fuchs, 11-5o. St. Gallen: Typotron AG, 1998.

Wood, Karl E. Health and Hazard: Spa Culture and the Social History of Medicine in the Nineteenth Century. Newcastle upon Tyne: Cambridge Scholars Publishing, 2012.

Wyder, Margrit. Kräuter, Kröpfe, Höhenkuren: die Alpen in der Medizin - die Medizin in den Alpen; Texte aus zehn Jahrhunderten. Zurich:Verlag NZZ, 2003.

Zimmer, Oliver. "In Search of Natural Identity: Alpine Landscape and the Reconstruction of the Swiss Nation." Comparative Studies in Society and History 40, no. 4 (1998): $637-65$. 